\title{
OPTYMIZM ANTROPOLOGICZNY W ŚWIETLE NAUKI O GRZECHU PIERWORODNYM
}

Mówienie o człowieku stało się wyjątkowo trudne. Coraz bardziej zauważalna staje się tendencja do redukcjonistycznego pojmowania osoby ludzkiej. Redukcja ta wpływa z kolei destrukcyjnie na rozumienie godności osoby ludzkiej, jej podstawowych właściwości, praw i obowiązków. Błędna antropologia z konieczności prowadzi również do błędnej moralności. Ta zaś rzutuje na społeczeństwo i obowiązujące w nim prawa i relacje. Fałszywa antropologia może w ten sposób doprowadzić do rozkładu społeczeństwa, a nawet wielkich tragedii. Niezbędne wydaje się więc nieustanne konfrontowanie objawionej prawdy o człowieku ze współczesnymi nurtami myślowymi.

\section{WSTĘP}

Wielu naukowców, szczególnie anglojęzycznych, podejmuje dyskusje na temat istoty i natury człowieka. Coraz częściej wysuwa się w filozofii, socjologii i teologii, a nawet polityce postulat konieczności ponownego przemyślenia tego, kim jest człowiek. Nowe uwarunkowania geopolityczne i kulturowe, dyktat relatywizmu i pesymizm teoriopoznawczy skłaniają wiele środowisk do prowadzenia badań antropologicznych mających na celu ukazanie „nowego człowieka”, wyzwolonego, równego, niczym nieograniczonego.

$\mathrm{W}$ prezentowanym artykule postanowiłem zmierzyć się z pytaniem o powszechny dziś optymizm antropologiczny w perspektywie katolickiej nauki o grzechu pierworodnym. Za bazę biblijną przyjmuję dwa fragmenty Pisma Świętego: Rz 5,12 i Mdr 2,23-24. Wnioski płynące z tekstu biblijnego uzupełniam o wypowiedzi Magisterium Kościoła i teologów. Analiza zebranych danych pozwoli mi odpowiedzieć na pytanie: Jak rozumieć ideę optymizmu antropolo-

\footnotetext{
Ks. mgr lic. Przemysław Przyślak - doktorant Papieskiego Wydziału Teologicznego we Wrocławiu, e-mail: Przemek.przyslak@gmail.com; ORCID: 0000-0001-8475-5248.
} 
gicznego w świetle katolickiej nauki o grzechu pierworodnym? W moim artykule przyjmuję synkretyczną metodologię. Z konieczności przyjdzie mi łączyć elementy egzegezy biblijnej $\mathrm{z}$ metodami teologii dogmatycznej. W pierwszej części artykułu prezentuję optymizm antropologiczny. Dokonam próby definicji omawianego zjawiska, po czym opiszę jego recepcję na trzech polach: ontologicznym, społecznym i biomedycznym. Następnie przestawię wybrane fragmenty Pisma, a wnioski aplikuję do omówienia doktryny o grzechu pierworodnym. To pozwoli dokonać oceny idei optymizmu antropologicznego.

Tak zaplanowana praca wymusza konkretną jej strukturę. Najpierw zajmę się prezentacją optymizmu antropologicznego. Wyjaśnię to pojęcie i podam jego charakterystyczne założenia w świetle filozofii J.J Rousseau, Manifestu Partii Komunistycznej oraz transhumanizmu. Następnie dokonam analizy wybranych tekstów biblijnych. Kolejnym krokiem będzie ocena współczesnego trendu antropologicznego w świetle tekstów biblijnych i osadzenie go w szerszym kontekście nauki o grzechu pierworodnym. To doprowadzi do wskazania sedna błędu optymizmu antropologicznego i możliwości jego przezwyciężenia oraz sformułowania wniosków.

\section{OPTYMIZM ANTROPOLOGICZNY}

\section{POJĘCIE OPTYMIZMU ANTROPOLOGICZNEGO. PRÓBA DEFINICJI}

Jako oddzielne pojęcie filozoficzne termin ten nie występuje w większych słownikach filozoficznych. Można jednak bez problemu zauważyć jego funkcjonowanie w myśli wielu filozofów, szczególnie od czasu oświecenia. W filozofii w ogóle optymizm oznacza pozytywne myślenie o świecie mimo przeciwności losu, stan ducha wynikający z aktywności człowieka. Samo pojęcie optymizmu jako takie w filozofii jest łączone z jakimś konkretnym jej działem bądź poglądem.

Opisywany poniżej pogląd na człowieka zostanie przedstawiony $\mathrm{w}$ trzech aspektach: w ujęciu Jeana Jakuba Rousseau, w wizji Manifestu ekonomicznego oraz w perspektywie współczesnego transhumanizmu i prób udoskonalania gatunku ludzkiego. Dla integralności tego artykułu należy jednak zdefiniować pojęcie optymizmu antropologicznego.

Za optymizm antropologiczny uznaję taką wizję człowieka, która zakłada, że jest on z natury dobry, a jego niczym nieskrępowana wolność w podejmowaniu swoich aktów dokonuje zawsze dobrego wyboru, o ile tym wyborem nie narusza on prawa pozytywnego bądź wolności drugiego człowieka. Ów optymizm charakteryzuje się odkrywaniem prawdy w aktach osoby jako właściwych indywi- 
dualnej jednostce. Prawda nie leży poza człowiekiem, jest z nim zintegrowana, więc każdy odkrywa prawdę w sobie, sam ją niejako konstytuuje. Nikt nie może definiować prawdy obiektywnej, o ile nie jest to konieczne dla ustalenia porządku publicznego. Jeśli jednak prawo stanowione miałoby naruszać absolutną wolność człowieka i jego prawo do tworzenia prawdy o sobie, musi zostać zmienione.

Tak rozumiana antropologia rozwijała się właściwie od XVII wieku. Swoją szczególną fazę rozwoju osiągnęła w wieku XIX, kiedy sformułowane zostały tezy Marksa. Po raz kolejny przetransformowała się pod koniec lat sześćdziesiątych XX wieku, by móc osiągnąc szczytowy rozwój we współczesnej eugenice, transhumanizmie i ideologii gender ${ }^{1}$.

\section{JAN JAKUB ROUSSEAU}

„Wszystko jest dobre, gdy opuszcza ręce swojego Autora, a staje się złe, gdy wpada w ręce człowieka" ${ }^{2}$. Tak Rousseau rozpoczyna jedno ze swoich najbardziej znanych dzieł. Mówiąc o konieczności edukacji, stwierdza, że jeśli człowiek urodził się duży i silny, to nie wie, jak swojej siły użyć, jeśli nie zostanie wyedukowany. Podobnie jak roślina wzrasta dzięki uprawianiu, tak człowiek dojrzewa przez wychowanie ${ }^{3}$. Człowiek rodzi się z ogromną pulą możliwości, ale zostają one ograniczone przez kulturę $e^{4}$ Rozważając wrodzone możliwości człowieka, Rousseau stwierdza: ,zanim dokona się ta korupcja, jest w nas coś, co nazywam natura" ". Myśliciel zdaje się wskazywać na wrodzoną dobroć i możliwości człowieka. Człowiek rodzi się z paletą pewnych umiejętności, które muszą zostać rozwinięte przez wychowanie. Pojawia się jednak problem kultury ludzkiej, która degraduje wrodzoną „idealność” człowieka. Swoje rozważania na temat natury człowieka zawiera również w jednej z dysertacji na ten temat ${ }^{6}$. Owa idealność jest jednak specyficzna. Człowiek naturalny nie posiada bowiem umiejętności używania rozumu, robi więc wszystko zgodnie z prawem natury. Właśnie owo bezwzględne posłuszeństwo prawom natury czyniło człowieka prawdziwie wolnym ${ }^{7}$.

\footnotetext{
1 Świetną pracę na ten temat napisała francuska filozof Chantal Delsol: Nienawiść do świata. Totalitaryzmy i ponowoczesność, tłum. M. Chojnacki, Warszawa 2017. Zob także Ch. Delsol, Esej o człowieku późnej nowoczesności, tłum. M. Kowalska, Warszawa 2003.

2 J.J. Rouseau, Emil, or on Education, Basic Books 1979, s. 37.

Tamże, s. 38.

Tamże, s. 39.

Tamże.

6 J.J. Rouseau, Origin and Foundations of Inequality Among Mankind, w: The Social Contract and the First and Second Discourses, Yale University 2002, s. 69-148.

7 S. Zawadzka, Wolność ludzka w ujęciu Jana Jakuba Rousseau, „Studia Philosophiae Christianae UKSW" 52 (2016) 1, s. 121-135.
} 
Prawa natury człowiek sam sobie narzucał i był im z konieczności posłuszny ${ }^{8}$. Rozum sprawia, że człowiek jest nieposłuszny tym prawom i je łamie ${ }^{9}$. Rousseau twierdził także, że podstawowym prawem natury jest miłość siebie i konieczność samorealizacji każdego bytu, w tym także człowieka ${ }^{10}$. Do tego konieczna jest jednak wolność, która przysługuje człowiekowi również w społeczeństwie ${ }^{11}$. Jest ona dla człowieka naturalna i polega na spełnianiu praw natury, czyli dążeniu do zaspokojenia. Człowiekowi zatem, nawet poza stanem pierwotnym, uwikłanemu w rozum, powinna przysługiwać wolność. Tylko ona daje szansę pełnego rozwoju człowieka. Spontaniczność i pierwotne odruchy serca są bardziej pierwotne względem rozumu ${ }^{12}$, dlatego należy im się pierwszeństwo. Rozum powoduje wręcz, że dobre odruchy zamieniają się w złe czyny, kiedy są rozważane ${ }^{13}$. W sposób naturalny człowiek skupia się na samym sobie i powinien dążyć do realizacji siebie ${ }^{14}$.

Widać zatem wyraźnie, że Rousseau pokłada ogromną nadzieję w człowieku i gloryfikuje jego pierwotne odruchy. Zaspokajanie niskich, przedrozumowych potrzeb jest dlań właściwą realizacją wolności, którą rozum i refleksja jedynie ograniczają. Dlatego nie można ograniczać człowieka, gdyż on już sam siebie wystarczająco ogranicza. Dla podjętego przeze mnie tematu jest to niezwykle ważne stanowisko. Można bowiem na podstawie myśli Rousseau wysnuć następujący wniosek: wszelkie ograniczanie ludzkich popędów powodowane rozumową refleksją nad nimi jest gwałtem zadanym wolności.

\section{MANIFEST PARTII KOMUNISTYCZNEJ}

\section{Zarys myśli marksistowskiej}

Niektórzy badacze uważają, że na rozwój myśli Marksa i Engelsa znacząco wpłynął niemiecki idealista Georg Hegel. Według niektórych autorów dla Marksa filozofia przedheglowska jest irracjonalnym nonsensem ${ }^{15}$. Wydaje się, że Marks

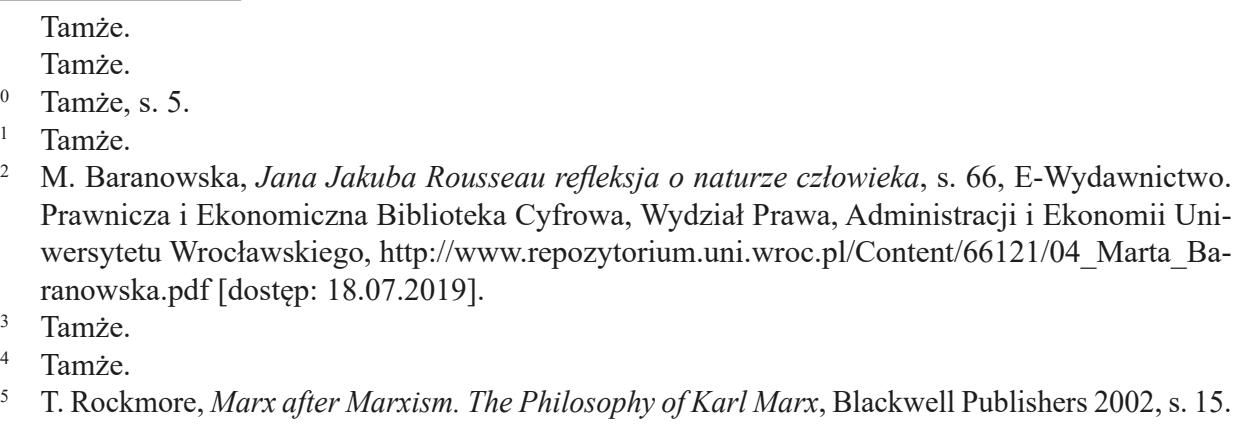
Prawnicza i Ekonomiczna Biblioteka Cyfrowa, Wydział Prawa, Administracji i Ekonomii Uniwersytetu Wrocławskiego, http://www.repozytorium.uni.wroc.pl/Content/66121/04_Marta_Baranowska.pdf [dostęp: 18.07.2019].

Tamże.

Tamże.

T. Rockmore, Marx after Marxism. The Philosophy of Karl Marx, Blackwell Publishers 2002, s. 15. 
bardzo szybko zaczął się interesować Heglem, jeszcze zanim sam rozpoczął pisanie $^{16}$. Nie znaczy to jednak, że był jego kopistą. Krytykował Filozofię prawa Hegla, jednak już w Kapitale odwołuje się do tego filozofa, komentuje jego dzieła chociażby w Manuskrypcie paryskim, przyjmując pewne elementy jego metody, a Logika Hegla miała spory wpływa na Kapita ${ }^{17}$.

Czy Hegel uznałby Marksa za swojego ucznia? Zapewne nie, chociażby dlatego, że jego panteistyczne koncepcje w marksizmie przeradzają się w naturalizm i ateizm. Dochodzi również do zrewolucjonizowania koncepcji społecznych ${ }^{18}$. Sam Marks z pewnością też nie uznałby się za heglistę.

Za podstawowe założenie filozofii marksistowskiej można uznać jej pragmatyczny charakter. Jak głosi jedenasta teza o Feuerbachu: „Filozofowie na różny sposób interpretowali świat, a mają go przekształcać" ${ }^{19}$. Chęć przemieniania świata determinowała myśl Marksa i Engelsa. Konfrontując się z innymi socjalistami, wyrażali pragnienie powrotu do społeczeństwa opartego na szczęśliwej wspólnocie pierwotnej ${ }^{20}$. Sam Engels zauważa, że „w swej formie teoretycznej” socjalizm jawi się jako „konsekwentniejsze rozwinięcie zasad wysuniętych przez wielkich francuskich myślicieli Oświecenia XVIII stulecia"21. W tym samym miejscu Engels stwierdza, że wszystko - religia, społeczeństwo, ustrój państwowy - muszą poddać się bezlitosnej krytyce rozumu albo przestać istnieć, ,,wyrzec się własnego istnienia”, jak sam stwierdza ${ }^{22}$. Dodaje przy tym, że „myślący rozum stał się jedynym probierzem"23. Idąc za Heglem, Engels postuluje oddanie rzeczywistości pod osąd ludzkiego rozumu, który sam koncypuje i wytwarza prawdy - mierniki rzeczywistości ${ }^{24}$. Następnie Engels dochodzi do jednego z fundamentalnych zdań:

Dopiero teraz zajaśniało światło dzienne, nastąpiło Królestwo rozumu; odtąd zabobon, bezprawie, przywilej i ucisk miały zostać wyparte przez wieczną prawde, wieczną sprawiedliwość, ZAŁOŻONĄ W NATURZE RÓWNOŚĆ i niezbywalne prawa człowieka ${ }^{25}$.

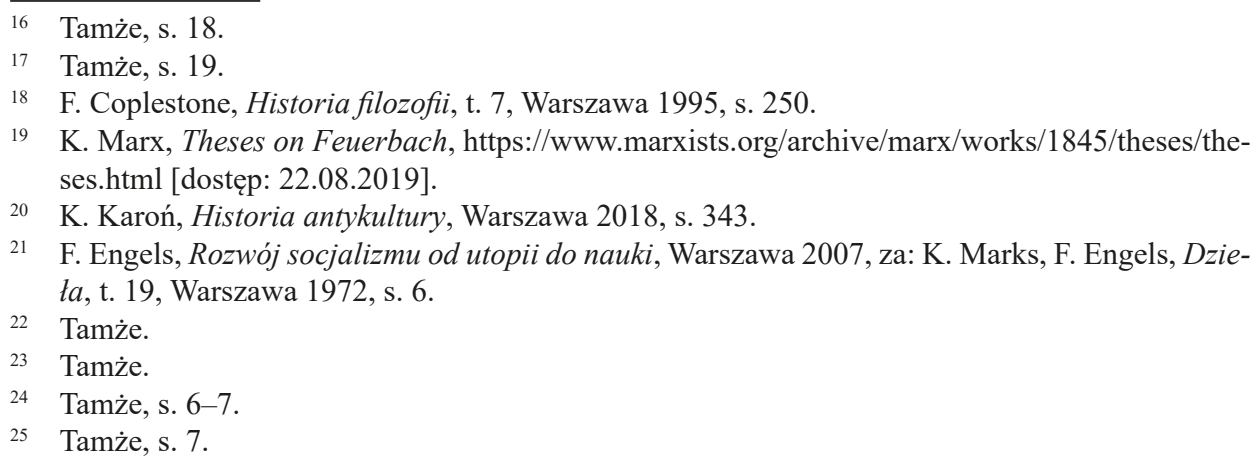

21 F. Engels, Rozwój socjalizmu od utopii do nauki, Warszawa 2007, za: K. Marks, F. Engels, Dzieta, t. 19, Warszawa 1972, s. 6. 
Te założenia heglizmu i filozofii Rousseau Engels przyjmuje, ale krytykuje w sposobie ich realizacji. Zauważa, że nie mogły się one zrealizować inaczej, jak przez burżuazyjną demokrację, wyzysk „,pracujących biedaków” przez „bogatych próżniaków"26. Swoje stanowisko Engels konfrontuje w prostym przekroju: świat - proletariat. Oświeceniowcy chcą zbawić zrazu cały świat. Engels walczy o prawa proletariatu ${ }^{27}$. Zauważa również upadek „rozumu społecznego”. Uważa, że różnica między bogactwem i nędzą nie roztopiła się w powszechnym dobrobycie, ale zaostrzyła ${ }^{28}$. W socjalizmie szuka więc lekarstwa, które pozwoliłoby ludzkości przezwyciężyć dyktaturę bogatych próżniaków i doprowadzić do prawdziwej równości wszystkich ludzi.

W tej perspektywie Marks podaje teorię alienacji, według której człowiek jest odsunięty od możliwości sterowania procesami, w których bierze udział. Alienacja sprawia, że osoba ludzka żyje w sposób nie w pełni ludzki. Marks nazywa ten proces dehumanizacją ${ }^{29}$.

\section{Manifest Partii Komunistycznej. Aspekty antropologiczne}

Podstawowym spostrzeżeniem Manifestu komunistycznego jest dostrzeżenie nierówności społecznej. Jego autorzy dość ostro dzielą świat na wolnych i niewolników, patrycjuszy i plebejuszy, feudałów i chłopów poddanych, majstrów cechowych i czeladników ${ }^{30}$. Ten ostry podział można zawrzeć ostatecznie $\mathrm{w}$ donośnym stwierdzeniu Marksa i Engelsa:

[...] ciemięzcy i uciemiężeni pozostawali w stałym do siebie przeciwieństwie, prowadzili nieustanną, juz to ukrytą, juz to jawną walke - walke, która za każdym razem kończyła sie, rewolucyjnym przeobrażeniem całego społeczeństwa albo wspólna. zagładą walczących klas ${ }^{31}$.

Dlaczego ta nierówność społeczna tak uderza obu komunistów? Zdaje się, że głównym motywem ich krytyki jest dostrzeżona przezeń degradacja godności człowieka:

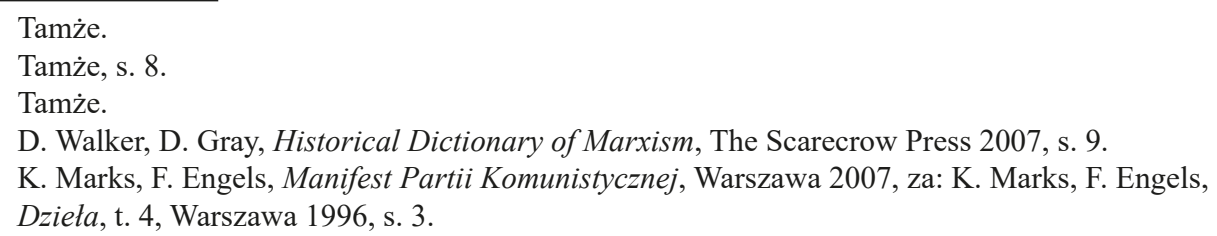


Burżuazja tam, gdzie doszła do władzy, zburzyła wszystkie feudalne, patriarchalne, idylliczne stosunki. Pozrywała bezlitośnie wielorakie więzy feudalne, które przykuwały człowieka do jego ,naturalnego zwierzchnika” i nie pozostawiła między ludźmi żadnej innej więzi prócz nagiego interesu, wyzutej z wszelkiego sentymentu ,zapłaty gotówka”. Świątobliwe dreszcze pobożnej egzaltacji, rycerskiego zapału, drobnomieszczańskiej rzewności zatopiła w lodowatej wodzie egoistycznego wyrachowania. Godność osobistą sprowadziła do wartości wymiennej, a zamiast niezliczonych uwierzytelnionych dokumentami, dobrze nabytych wolności wprowadziła jedną jedyną, pozbawioną sumienia, wolność handlu. Słowem, wyzysk osłonięty złudzeniami religijnymi i politycznymi zastąpiła wyzyskiem jawnym, bezwstydnym, bezpośrednim, nagim ${ }^{32}$.

Nierówność i rozdźwięk społeczny, niejednolita tkanka społeczna i mechanizm kapitalistyczny, który wynosił na wyżyny społeczne posiadaczy dóbr prywatnych, a robotników-proletariuszy skazywał na, nazwijmy to, nową formę niewolnictwa, tym razem zawoalowanego w postaci prostej konstrukcji: praca - zapłata. Ta konstrukcja wydawała się jednak dla Marksa i Engelsa o tyle niestosowna, o ile robotnicy nie mogli uczestniczyć w posiadaniu wypracowanych dóbr. W związku z tym postulowali oni „zniesienie własności prywatnej” 33 . Propozycja twórców Manifestu niesie ze sobą liczne konsekwencje prawne, społeczne i ekonomiczne. Jak jednak przyczynia się do rozwoju optymizmu antropologicznego? Zniesienie prawa własności jest pierwszym krokiem w procesie egalitaryzacji społeczeństwa. Ujednolicenie potrzeb i zrównanie wszystkich we wszystkich prawach, innymi słowy: pomiędzy zniesieniem własności prywatnej a absolutną wolnością (będącą podłożem optymizmu antropologicznego) jest krótka droga ideologiczna. Ujednolicone społeczeństwo egalitarne nie może być uciskane przez żadną grupę rządzącą. Jedynie wewnętrzny imperatyw grupy może nią w jakikolwiek sposób sterować. To, co Marks i Engels nazywali burżuazją, może być tak naprawdę wszystkim: państwem, Kościołem, zakładem pracy. Równość ekonomiczna, która w XIX wieku niweluje wszelkie podziały klasowe na burżuazję i proletariat, w wieku XXI ekspanduje na kolejne obszary życia człowieka. Równość staje się jednym z podstawowych praw, które mają rządzić społeczeństwem. Ostatnim zaś bastionem podziału jest płeć. Jeśli zniesie się różnicę między płciami albo uda się wmówić społeczeństwu, że płeć biologiczna nie ma znaczenia, uda się w pełni zrealizować ideały Marksa i Engelsa ${ }^{34}$. W celu urzeczywistnienia swojej wizji myśliciele socjalistyczni uznają za konieczne zerwanie z tradycją: „,w społeczeń-

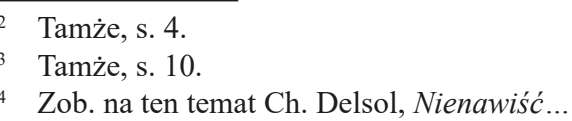


stwie burżuazyjnym przeszłość panuje więc nad teraźniejszością, w społeczeństwie komunistycznym - teraźniejszość nad przeszłością" ${ }^{35}$. Następnie stwierdzają stanowczo, że chcą zniesienia burżuazyjnej osobowości, samodzielności i wolności ${ }^{36}$, gdyż burżuazyjny kapitał je posiada, a jednostka jest ich pozbawio$n^{37}$. Okazuje się zatem, że społeczeństwo klasowe systemowo niejako ogranicza wolność jednostki, czyniąc ją przedmiotem operacji kapitalistycznych. Zniesienie własności prywatnej nie jest zniesieniem własności w ogóle, ale zniesieniem własności burżuazyjnej. Jaka to własność burżuazyjna? Taka, w której posiada jeden na dziesięciu, podczas gdy dziewięciu na dziesięciu nie ma prawa własności, chociaż zarobkuje. Tu Engels i Marks widzą zawieszenie wolności jednostki ${ }^{38}$.

Idą za tym o wiele poważniejsze konsekwencje, niż mogłoby się wydawać. To, co w momencie publikacji Manifestu zdaje się doktryną czysto ekonomiczną, w roku 1968 wybucha w postulatach społecznych. Tym razem jednak przekraczających granice gospodarcze. Żąda się absolutnej równości we wszystkich przejawach życia społecznego. Twórcy Manifestu są zresztą świadomi tego, że zniesienie własności prywatnej jest jedynie początkiem przemian. Nie tylko nie ukrywają tego, że „rewolucja komunistyczna jest najradykalniejszym zerwaniem z tradycyjnymi stosunkami własności; nic dziwnego, że w swym przebiegu przyniesie ona również najradykalniejsze zerwanie z tradycyjnymi ideami”'39, ale wręcz oczekują szybkiej realizacji tego założenia. Przez tradycyjne idee rozumie się tutaj oczywiście idee religijne, filozoficzne, moralne, prawne, polityczne, słowem wszystko, co tworzyło dotychczasowy ład społeczny. „Komuniści popierają wszędzie każdy ruch rewolucyjny przeciw istniejącym stosunkom społecznym i politycznym"40. Taka idea bazowa musiała w końcu doprowadzić do tego, co postulowała.

Jak łatwo zauważyć, Marks i Engels opierają swoje założenia na podobnym do Rousseau założeniu antropologicznym. Nic nie może ograniczać pierwotnej wolności człowieka. Wolność absolutna i absolutna równość są podstawą nowego ustroju społecznego, który ma zapalić cały świat: wszak swój Manifest niemieccy socjaliści kończą znamiennym zawołaniem: „Proletariusze wszystkich krajów, łączcie się!”. Chociaż sam Manifest nie porusza kwestii antropologicznych w sposób metodologicznie usystematyzowany, to jednak przedkłada wizję świata możliwą do realizacji tylko na podstawie niczym nieskrępowanej wolności, dają-

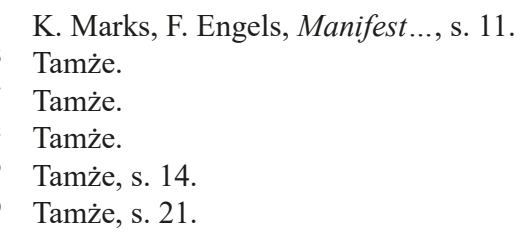


cej przyzwolenie na realizację wszystkich potrzeb człowieka. Wszystko bowiem, co wprowadza jakikolwiek podział, jakąkolwiek dystynkcję, jakiekolwiek ograniczenie - jest burżuazyjne i należy to znieść. I w tym sensie Manifest jest fazą przejściową między ideą Rousseau i transhumanizmem. Nie wprowadza jeszcze wprost idei wolności absolutnej w sferze moralnej, politycznej czy każdej innej, ale zaznacza, że zerwanie na drodze rewolucji z przeszłością jest konieczne dla osiągnięcia zamierzonego celu, jakim jest uszczęśliwienie człowieka.

\section{TRANSHUMANIZM}

Trzecim, najbardziej dojrzałym przejawem optymizmu antropologicznego jest transhumanizm. Pod pojęciem transhumanizmu rozumie się najczęściej „ruch zwolenników wykorzystania dostępnych technik, w tym neuro-, bio- i nanotechnologii, w celu ulepszenia gatunku ludzkiego"41. Formę egzystencji człowieka przetransformowaną przez technikę zwykło się nazywać posthumanizmem ${ }^{42}$. Dążenie do ulepszenia gatunku ludzkiego wydaje się podyktowane racjonalnymi argumentami. Dlaczego, zdają się pytać transhumaniści, nie mielibyśmy wykorzystać dostępnej nam techniki i coraz szerszej wiedzy biomedycznej do podniesienia jakości życia człowieka? Takie podejście rodzi oczywiście liczne wątpliwości, przede wszystkim o granice ingerencji w organizm ludzki. Spory trwające między transhumanistami a biokonserwatystami ześrodkowują się przede wszystkim wokół idei wrodzonej godności osoby ludzkiej i wolności człowieka.

\section{Transhumanizm. Założenia ogólne}

Transhumanizm dąży przede wszystkim do tego, by człowiek przekraczał ograniczenia wbudowane w ludzką kondycję, jakich obecnie doświadcza ${ }^{43}$. Człowiek zdaje się organizmalnie słabo zoptymalizowany ${ }^{44}$, nie dorasta do poziomu wyprodukowanych przez siebie robotów i maszyn. J. Bolter przedstawia człowieka jako maszynę biochemiczną, której hardware to aparat biochemiczny (tkanki, enzymy, białka itd.), a software to nasz mózg ${ }^{45}$.

\footnotetext{
${ }_{41}$ M. Soniewicka, Transhumanizm: kilka uwag na temat filozoficznych źródet sporu o ideę biomedycznego ulepszania moralnego, „Ethics in Progress” 6 (2015) 38-55, s. 39.

42 Zob. tamże.

43 Zob. tamże.

44 Zob. P. Ciniewski, Ambiwalencja transhumanizmu wobec cielesności, „Filozofia i Nauka. Studia Filozoficzne i Interdyscyplinarne" 5 (2017) 105-116, s. 108.

45 Tamże.
} 
Nie ulega wątpliwości, że bazowe założenie posthumanizmu jest altruistyczne. Transhumaniści odwołują się do ideałów oświecenia i postulują postawienie człowieka $\mathrm{w}$ centrum zainteresowania nauki ${ }^{46}$. Skoro bowiem człowiek jawi się jako przestarzały sprzęt, powinien zostać zaktualizowany i ulepszony do najnowszej możliwej wersji za pomocą zdobyczy nauki i techniki. Ból i cierpienie należy wyeliminować, a możliwości ludzkie zoptymalizować ${ }^{47}$. Jeśliby założyć, że doświadczenie bólu i cierpienia jest związane nie tylko z doświadczeniem sensualnym, ale również emocjonalnym ${ }^{48}$, oraz że wpływa nań świadomośćc ${ }^{49}$ człowieka, to należy stwierdzić, że większa samoświadomość wpływa jakoś na przeżywanie cierpienia. Człowiek w XXI wieku doświadcza bardziej niż kiedykolwiek bólu egzystencjalnego. By go uśmierzyć, potrzebuje nowych metod. Transhumanizm chce zatem nie tylko dostarczyć „,części zamiennych” dla nowego człowieka. Postuluje również zaprojektowanie nowego duchowo człowieka. Jak zauważa J. Harris:

Doniosłym jest, że osiągnęliśmy punkt w rozwoju ludzkiej historii, w którym dalsze próby, by uczynić świat lepszym miejscem, będa musiały obejmować nie tylko zmiany świata, ale równiez zmiany ludzkości, w konsekwencji czego być może my bądź nasi potomkowie przestaniemy być ludźmi w znaczeniu, w którym teraz rozumiemy to pojęcie ${ }^{50}$.

Nauka dąży zatem do ziszczenia wizji świata proponowanej przez Aldousa Huxleya w jego kultowej powieści Nowy wspaniaty świat. Huxley nadaje jednak swojej powieści antyutopijny charakter, z kolei dzisiejsi naukowcy, posthumaniści zdają się raczej wierzyć w utopię nowego świata i nowego człowieka. Człowieka wyzwolonego ostatecznie z zepsucia śmierci.

\section{Transhumanizm. Natura ludzka}

Istotnym elementem doktryny posthumanistycznej będzie dla mnie jej rozumienie natury ludzkiej. Cytowana już M. Soniewiecka zauważa, że podobnie jak humaniści renesansowi, posthumaniści ponowocześni zdają się postulować

\footnotetext{
Tamże.

Tamże.

48 Ten sam ból może być w skali od 1 do 10 różnie odbierany i przeżywany przez dwie różne osoby.

49 Ten sam ból będzie inaczej przeżywany przez osobę, która wie, że ma raka, a inaczej przez taką, która tej świadomości nie ma.

$50 \quad$ M. Soniewiecka, Transhumanizm..., s. 39.
} 
nieokreśloność i nieograniczoną wolność w samokształtowaniu natury ludzkiej. Człowiek może i powinien przekraczać siebie, by osiągnąć wyższy poziom rozwoju $^{51}$. Dlatego zwolennicy ulepszania biomedycznego nie widzą formalnej różnicy między wychowaniem a udoskonalaniem genetycznym człowieka. Jest to jedynie różnica stopnia ingerencji. Zarówno bowiem wychowanie, jak i manipulacje genetyczne kształtują człowieka bez jego świadomości i pozostawiają trwały, często nieodwracalny ślad ${ }^{52}$.

Transhumaniści napotykają pewne trudności w określeniu, czym właściwie jest natura ludzka. Fukuyama, zauważając problem w „świeckim” definiowaniu natury, dochodzi ostatecznie do przekonania, że jest to suma cech i zachowań właściwa gatunkowi ludzkiemu wynikająca z uwarunkowań genetycznych, a nie środowiskowych ${ }^{53}$. Natura ta jednak nie jest niezmienna, przynajmniej w sensie biologicznym. Można bowiem dokonać szeregu zmian, które doprowadzą do optymalizacji jednostkowego istnienia. Kluczowe jednak staje się zdanie, że zabiegi biomedyczne mają doprowadzić do naprawienia bądź wzmocnienia cech $\mathrm{z}$ natury dobrych ${ }^{54}$. Owo wzmocnienie cech natury ludzkiej odbywać by się miało na dwóch poziomach: funkcjonalnym (funkcje organizmu) i ontycznym (poprawa samej istoty bytu $)^{55}$. Krytycy transhumanizmu zauważają, że nie da się oddzielić przemian biologicznych bez odniesienia do metafizycznej struktury bytu ${ }^{56}$. Pojawia się bowiem techniczna możliwość przeszczepienia człowiekowi genów innych gatunków, które mogłyby wydłużyć życie czy poprawić funkcjonowanie niektórych zdolności naturalnych ${ }^{57}$. Co stanowi miarę konieczności zmiany? Miarą tą jest samopoczucie. Człowiek może ingerować we własną naturę o tyle, o ile poprawi to jego samopoczucie i sprawi, że „będzie mu się lepiej żyło" 58 . Tego typu labilność (wszak samopoczucie jest chyba najbardziej subiektywnym pojęciem - różne jest nie tylko u poszczególnych ludzi, ale nawet u tego samego człowieka i zależy od wielu czynników nań oddziaływujących) sprawia, że nie ma mowy o jednej, niezmiennej i stałej naturze ludzkiej, wspólnej wszystkim

51 Tamże, s. 40.

52 Zob. tamże, s. 43.

53 Zob. A. Alichniewicz, M. Michałkowska, Udoskonalanie gatunku ludzkiego - problemy definicyjne i argumentacyjne, „Principia” LXIV (2017), s. 225-255.

54 M. Ferdynus, Czy biomedyczne doskonalenie natury jest ,zabawa w Boga”? „Studia Warmińskie" 50 (2013) 9-22, s. 14.

55 Tamże, s. 10-11.

56 Tamże.

57 Możliwości techniczne już dzisiaj pozwalają na podobne eksperymenty, a za 30 lat będzie to prawdopodobnie nasza codzienność. Zob. G. Lindenberg, Ludzkość poprawiona. Jak najbliższe lata zmienią świat, w którym żyjemy, Kraków 2018. Warto zwrócić szczególną uwagę na rozdz. IV (Człowiek poprawiony) i V (W stronę nieśmiertelności).

58 M. Ferdynus, Czy biomedyczne..., s. 13-14. 
przedstawicielom gatunku homo sapiens. Zdaje się nie istnieć coś takiego jak „człowiekowatość”, gdyż byłaby ona zbyt niezmienna. Natura ludzka w sensie metafizycznym w tym przypadku z konieczności musi odrzucać jakikolwiek pierwiastek duchowy, gdyż jako niematerialny nie podlega on zmianom biomedycznym. Kiedy jednak uda się wszczepić w DNA człowieka fragment np. DNA słonia, to z genetycznego punktu widzenia mamy już jakiś nowy gatunek? A przecież ingerencja taka nie mogłaby w żaden sposób wpłynąć na duszę ludzką. Doszłoby zatem do rozdźwięku między statusem ontycznym człowieka (człowiek - osoba ludzka) a jego statusem fizycznym (genetyczny mutant). Widać zatem wyraźnie, że transhumanizm musi zakładać czysty materializm. Dzięki rozumieniu człowieka jako bytu czysto materialnego można dopuścić dowolną na nim manipulację, nawet transgatunkową. Zdaje się potwierdzać to wspomniany już Fukuyama, który zauważa, że natura ${ }^{59}$ ludzka nakłada jednak na badaczy pewne ograniczenia i zakreśla stopień i granice modyfikacji genetycznych ${ }^{60}$. Podobne spostrzeżenie czyni Engelhardt:

Odwołanie do natury ludzkiej jako przewodnika moralnego zostało unieważnione albo przynajmniej poważnie ograniczone, odkąd nie możemy powołać się na zamysł, lecz jedynie na rezultaty ślepych procesów mutacji, dryfu genetycznego i selekcji natural$n \mathrm{j}^{61}$.

Transhumaniści odwołują się jednak do bardziej labilnej definicji natury ludzkiej, postrzegając ją jako proces zachodzący w czasie. Człowiek zaś może dowolnie tę swoją naturę kształtować i formować zgodnie z własną wolą ${ }^{62}$. Głęboka ingerencja w naturę człowieka uprawnia nawet „projektowanie” lepszego człowieka. Dziecko może stać się więc produktem ambicji rodzica, który postanowi zaingerować $\mathrm{w}$ nie $\mathrm{z}$ niemedycznych powodów ${ }^{63}$. Znów miarą zmiany staje się wola człowieka.

Transhumanizm zmienia zatem środek ciężkości. Podobnie jak Rousseau chce zaspokoić wszystkie pierwotne odruchy i potrzeby człowieka. Nie szuka jednak umocowania w określonej naturze ludzkiej, która byłaby sama z siebie dobra, dlatego każdy jej odruchowy, pierwotny, niemalże prymitywny przejaw powinien zostać zaspokojony. Transhumaniści rozumieją naturę jako coś zmiennego i da-

59 Rozumiana jako coś trwałego i niezmiennego.

60 A. Alichniewicz, M. Michałkowska, Udoskonalenie gatunku..., s. 249.

61 H.T. Engelhardt Jr., The Foundations of Bioethics, Oxford 1996, s. 412.

62 A. Alichniewicz, M. Michałkowska, Udoskonalenie gatunku ..., s. 250.

63 M.J. Sandel, The Case Against Perfection. Ethics in the Age of Genetic Engineering, Harvard University Press 2007, s. 49. 
jącego się kształtować. Stoją jednak na stanowisku, że wola ludzka jest niczym nieskrępowana. Nie tylko przejście od złego do dobrego, od chorego do zdrowego, ale również wzmacnianie, udoskonalanie i przekształcanie tego, co dobre, zdrowe, jest uzasadnione, jeśli tylko taka jest wola człowieka. Natura podlega procesowi przekształcania, ten z kolei jest podporządkowany antynomii lepsze gorsze. Transhumanizm nie wskazuje jednak na żadne obiektywne źródło norm porządkujących ten proces. Wartość człowieka staje się zależna od jego kwalifikacji, tyrania ulepszania pragmatycznie przesuwa centrum człowieczeństwa (naturę ludzką) ze sfery samego bycia do sfery osiągania wyników ${ }^{64}$. Stąd wola ludzka, która kieruje się ku optymalizacji procesów życiowych, poznawczych, społecznych itd., zawsze będzie szukała tego, co bardziej optymalne. Nauki biomedyczne mają za zadanie jej to umożliwić.

\section{OPTYMIZM ANTROPOLOGICZNY. PODSUMOWANIE}

Optymizm antropologiczny, który zakłada, że natura ludzka sama w sobie jest dobra, a wolna wola w swoich aktach podejmuje zawsze dobrą decyzję, został powyżej zaprezentowany $\mathrm{w}$ trzech przejawach: ontologicznym, społecznym i biomedycznym. Analizując je, starałem się wskazać na podejmowany w tym artykule problem: źródło optymizmu antropologicznego oparte na rozumieniu natury ludzkiej i wolności człowieka.

Rousseau wykazywał, że natura, rozumiana jako ontyczna właściwość bytu - konstytuanta człowieczeństwa - jest dobra i niezdegenerowana w swojej istocie. Człowiek rodzi się jako dobry, jest on sumą potencjalności, które powinny zostać rozwinięte w procesie wychowawczym. Zło, którego dokonują jednostki, nie pochodzi od natury ludzkiej, ale jest efektem złego wychowania. Na to złe wychowanie wpływa przede wszystkim ograniczenie wolności aktów pierwotnych. Człowiek pozbawiony możliwości realizowania spontanicznych pragnień jest niejako zmuszony do stania się złym. Kultura, nauka, filozofia czy religia zabijają w człowieku „dobrego dzikusa”. Człowiek pierwotny był moralny, bo nie znał deprawującej go kultury, która stworzyła normy, odbierając człowiekowi spontaniczność.

Marks i Engels w swojej doktrynie, szczególnie zaś w Manifeście, stoją na stanowisku, że burżuazja poprzez gospodarkę kapitalistyczną ogranicza wolność i godność człowieka. Kapitalizm dla niemieckich filozofów jawi się jako system

${ }^{64}$ K. Łukasiewicz, Nadnatura. Wizje człowieka przyszłości we współczesnej debacie naukowej, popularnonaukowej i fantastycznonaukowej, „Prace Kulturoznawcze” XIV (2012) 2, Natura (w) granica(ch) kultury, red. I. Topp, s. 5. 
opresji ekonomicznej. Należy go więc zdelegalizować na drodze rewolucji. Opresyjne instytucje, dzielące świat na biednych i bogatych, nie mają prawa wpływać chociażby na własność prywatną. Ich bastionem są stare doktryny moralne, religijne, społeczne, ekonomiczne i filozoficzne. Rewolucja z konieczności musi dotknąć nie tylko sferę gospodarczą. Dla zrealizowania postulowanych przez nią treści musi znieść również dotychczasowy porządek społeczno-religijno-filozoficzny. Wolność człowieka musi zatem stać się absolutna. Każdy człowiek ma być zrównany w dostępie do środków materialnych, a w konsekwencji wszelkie potrzeby i pragnienia człowieka muszą być zaspokajane i realizowane. Równość jest wewnętrzną koniecznością systemu Marksa i Engelsa, bez której nie istnieje prawdziwa, żądana przezeń wolność. Każde ograniczenie równości jest gwałtem zadanym osobowej godności człowieka. Równość ta, począwszy od sfery ekonomicznej, musi objąć wszystkie sfery życia, jeśli ma spełnić założenia rewolucji proletariackiej.

Transhumanizm z kolei za podstawową uznaje potrzebę ulepszania człowieka na drodze biomedycznej i genetycznej. Materialistyczne pojmowanie istoty ludzkiej pozwala zrównać ją z maszynami czy zwierzętami. Transhumanizm wydaje się najpełniejszą odpowiedzią na egalitaryzm Manifestu. Równość może bowiem zostać zapewniona nie tylko przez prawo. Staje się możliwa na poziome organizmalnym. Przekracza nawet granicę gatunkową. Wszak człowiek może wszczepić w siebie nawet fragment zwierzęcia, bakterii czy rośliny - $\mathrm{i}$ to na poziomie genetycznym. Jedyną miarą tego procesu jest wola człowieka. Natura ludzka ma tu wybitnie materialistyczny charakter. Nie stanowi ona konstytuanty istnienia konkretu, jakim jest człowiek. Nie stanowi elementu tożsamościowego, lecz zmienną, nieustannie dziejącą się przypadłość człowieka. Jest czymś, co czyni mnie mną, ale nie jest czymś, co czyni mnie człowiekiem jako takim. Natura jest zatem rozumiana jako biologiczno-genetyczny aspekt istnienia organizmu. Ma charakter ilościowy, a nie jakościowy i jako taka nie jest ani dobra, ani zła. Nos nie jest rozumiany jako nos Jana czy noga jako noga Jana, tzn. jako element przypadłościowy w naturze człowieka. Nos jest nosem samym w sobie, noga jest nogą samą w sobie, bez odniesienia do konkretnej jednostkowej egzystencji, dlatego można je dowolnie modelować, przekształcać czy wymieniać. Dobre jest to, co jest optymalne, każde zatem dążenie do optymalizacji jest z założenia dobre. Człowiek jest więc $\mathrm{w}$ nieustannym rozwoju ku przekraczaniu swoim granic i barier.

W ten sposób dość jasno ujawniło się źródło optymizmu antropologicznego - błędne rozumienie natury ludzkiej. Jest to koncepcja zrównująca człowieka z przyrodą, niedostrzegająca jego wyjątkowości na tle innych bytów, uznająca pierwotne i nieprzetworzone potrzeby za bezwarunkowo dobre. Nakazuje ona realizować najpierw postulat „odkulturalnienia” człowieka, czyli zerwania z tradycją, która ludzi ogranicza. Następnie należy wszystkich zrównać, by nie 
istniały podziały, które ograniczają wolność i degradują godność osobową. Tak skonstruowany człowiek, pozbawiony swojego podłoża duchowego, jest wolny w przekształcaniu i modyfikowaniu swojej natury. Jest na ścieżce optymalizacji. Natura, która nie jest stałym i konstytutywnym elementem istoty ludzkiej, lecz jedynie zmiennym i nieustannym procesem, ciągłą aberracją, nie może być ani zła, ani dobra. Nie decyduje o sprawnościach etycznych osoby ludzkiej, nie daje podstaw do zdobywania cnót. Ponieważ natura jest labilna, nie daje krytycznego odniesienia, które podawałoby w wątpliwość bezwarunkową dobroć wszystkich spontanicznych odruchów człowieka.

\section{ANALIZA RZ 5,12 I MDR 2,23-24}

\section{POWSZECHNOŚĆ GRZECHU W RZ 5,12}

W Liście do Rzymian św. Paweł dokonuje syntezy całej swojej soteriologii. Apostoł Narodów opisuje relację łaski do natury i kwestie usprawiedliwienia jeszcze szerzej niż w Liście do Galatów. Paweł opowiada się w za powszechnym powołaniem ludzi do wiary i zbawienia (Rz 1,16-17), zauważając, że jedynie przez wiarę można osiągnąć usprawiedliwienie (Rz 3,28). Temat ten był szczególnie ważny dla braci żyjących w Rzymie. Tamtejsza gmina składała się zarówno z chrześcijan pochodzenia żydowskiego (pozostając przy tym w żywotnej relacji z Kościołem w Jerozolimie ${ }^{65}$ ), jak i prosēlytoi - prozelitów, którzy, będąc poganami, przyjęli judaizm ${ }^{66}$, a także „bojących się Boga” pogan, przyjmujących nauczanie żydowskie, ale odrzucających obrzezanie, oraz wreszcie takich pogan, którzy pod wpływem nauk chrześcijan przyjmowali chrzest. Paweł pisze zatem do wspólnoty różnorodnej etnicznie ${ }^{67}$, która w czasach redakcji listu była raczej zdominowana przez etnochrześcijan ${ }^{68}$. Stąd problem pochodzenia usprawiedliwienia jest dla Pawła tak ważny. Adresaci mają bowiem różne doświadczenie religijne i wiedzę biblijną. Należy zauważyć, że tak zróżnicowana wspólnota nie pozostaje bez znaczenia teologicznego. Właśnie Rzym, który jest stolicą ówczesnego świata, gromadzi chrześcijan każdego możliwego pochodzenia. Dopiero tu realnie ukazuje się uniwersalizm Kościoła ${ }^{69}$,

65 J.A. Fitzmyer, Romans, New York 1993, s. 33.

66 Tamże, s. 29.

67 Tamże, s. 32-33.

68 Tamże.

69 Por. C.S. Dessain, The Acts of the Apostles, w: A Catholic Commentary on Holy Scripture, red. B. Orchard, E.F. Sutcliffe, Toronto 1953, s. 1025. 
zarysowany symbolicznie w Dz 2,9-11. Z tego powodu Paweł nie mógł poprzestać jedynie na wyjaśnieniu natury usprawiedliwienia. Musiał najpierw ukazać jej konieczność. Aby wyjaśnić, na czym polegał czyn zbawczy Jezusa, musiał najpierw usystematyzować naukę o powszechności grzechu i jego pochodzeniu. Wykład nauki o usprawiedliwieniu nie jest, rzecz jasna, jedynym celem napisania listu, ale stanowi ważny element dzieła Apostoła Narodów ${ }^{70}$.

Takie tło historyczne uświadamia czytelnikowi, że Paweł musiał wyjaśnić naturę usprawiedliwienia, dostępnego przez wiarę wszystkim narodom. Zgodnie bowiem z nakazem Pana Jezusa uczniowie mają iść i nauczać wszystkie narody (zob. Mt 28,19), ten zaś, „kto uwierzy i chrzest przyjmie, będzie zbawiony” (Mk 16,16). Wynika stąd jasno, że obietnica zbawienia została rozciągnięta również na pogan. Stąd przekrój społeczny Kościoła rzymskiego wskazuje na bezpośrednią realizację nakazu misyjnego Jezusa. „Wszystkie narody” zdają się uzupełniać obszar misyjny zakreślony w Mt 10,5-6. Te dane biblijne są ponadto ważnym punktem wyjścia dalszej analizy. Wskazują jasno, że zbawienie jest możliwe na poziome natury ludzkiej. Inaczej mówiąc, człowiek powołany jest do zbawienia ze względu na to, że jest obrazem i podobieństwem Boga $(\operatorname{Rdz} 1,26)$.

W Rz 5,12 Paweł uzupełnia ten obraz o przyczynę konieczności powszechnego zbawienia. Każdy człowiek potrzebuje usprawiedliwienia, gdyż wszyscy są poddani śmierci, która jest skutkiem grzechu. Grzech zaś wszedł na świat przez Adama. Argumentując w ten sposób, Paweł wpisuje się w żydowski sposób myślenia, według którego śmierć jest winą grzechu Adama i Ewy ${ }^{71}$. Ten sposób myślenia urealnia doświadczenie grzechu. Jest on przypadłością ludzką związaną z konkretnym czynem człowieka. Tak rozumiany grzech wskazuje również na odpowiedzialność za jego popełnienie ${ }^{72}$. Aby czytelnicy mogli lepiej zrozumieć myśl Pawła, apostoł posługuje się porównaniem: Adam - Chrystus. Komentatorzy zwracają jednak uwagę na to, że sama osoba Adama nie jest dla Pawła przedmiotem zainteresowania ze względu na niego samego, ale ze względu na Chrystusa ${ }^{73}$. W ten sposób ukazuje, że zbawienie jest osadzone w historii świata i powszechne ${ }^{74}$. Odwołując się do Adama, przywołuje na myśl całą ludzkość ${ }^{75}$. To spostrzeżenie jest kluczowe dla omawianego tu zagadnienia.

70 Szczegółowe kwestie egzegetyczne zostały w tym opracowaniu pominięte zarówno w odniesieniu do Rz, jak i Mdr. Praca nie jest ściśle egzegetyczna, korzystam z egzegezy pośrednio wybiórczo, tam gdzie jest to konieczne.

71 Zob. J. Dunn, Word Biblical Commentary, vol. 38a: Romans 1-8, Dallas 1988, s. 272.

72 Tamże.

73 J. Fitzmyer, Romans..., s. 406; B. Byrne, Romans, Collegville 1996, s. 173-174.

74 D.J. Moo, The Epistle to the Romans, William B. Eerdmans Publishing Co. 1996, s. 314.

75 Tamże, s. 316. 
Skoro mowa jest o optymizmie antropologicznym, to zrozumiałe się staje, że ta wizja musi dotyczyć jakoś całej ludzkości. Paweł sięga tu do samego początku historii świata, ukazując Adama, pierwowzór człowieka. Cechy konstytutywne Adama są cechami właściwymi całemu rodzajowi ludzkiemu. Adam jako praojciec posiada „pracechy”. Bóg stworzył go tak, żeby mógł on przez rodzenie przekazywać obraz i podobieństwo Boga. Niezwykła godność osobowa, wynikająca $z$ bycia obrazem i podobieństwem, zostaje jednak zaburzona przez grzech. Odtąd przez zrodzenie zostaje przekazana natura ludzka, ale już zraniona - śmiertelna. Kluczowe zdaje się zakończenie wersetu 12: „ponieważ wszyscy zgrzeszyli”. Egzegeci nie są zgodni co do ostatecznego thumaczenia użytego przez Pawła wyrażenia „eph' ho"76. Zdają się jednak wskazywać na powszechność śmierci, która została spowodowana grzechem Adama. Paweł nie podaje dokładnego mechanizmu przekazywania grzechu, uwydatnia jedynie jego powszechny charakter. J.R. Edwards zauważa, że Paweł nie rozważa od strony teoretycznej problemu grzechu, lecz śmierci. Ta z kolei jest konsekwencją grzechu ${ }^{77}$. To spostrzeżenie jest ważne, ponieważ dostrzeżona przez Pawła powszechność śmierci oznacza powszechność grzechu. Śmierć, niejako genetycznie połączona z grzechem, uświadamia czytelnikom, że niemożliwe jest, aby ktoś nie grzeszył. Owa niemożność niegrzeszenia, skoro rozciąga się na cały rodzaj ludzki, musi być zatem związana z naturą ludzką. Wydaje się zatem, że Paweł chce jednoznacznie wskazać, że nikt nie jest wolny od grze$\mathrm{chu}^{78}$. Wers ten jest kluczowy dla katolickiej nauki o grzechu pierworodnym. W dalszych wersetach Paweł nieustannie odwołuje się do tego założenia bazowego, że przez grzech jednego wszyscy są poddani mocy grzechu. Używa jednak znaczącego zwrotu: ei gar to tou henos paraptomati hoi polloi apethanon $^{79}$. W polskim thumaczeniu Biblii Tysiąclecia zdanie to zostało przełożone: „Jeżeli bowiem przestępstwo jednego sprowadziło na wszystkich śmierć" Inni tłumaczą: „Bo jeśli w następstwie upadku jednego człowieka umarło wielu" "1 , co wydaje się lepiej oddawać myśl zawartą w tekście greckim. W ten sposób nieustannie uświadamia czytelnikom, że śmierć ma wymiar metafizyczny.

$76 \quad$ J. Fitzmyer, Romans..., s. 413-416.

77 J.R. Edwards, Romans, Baker Books 1992.

$78 \mathrm{Na}$ ten temat zob. L.T. Johnson, Reading Romans. A Literary and Theological Commenatry, Smyth \& Helwys Publishing 2001, s. 94.

79 B. Aland, K. Aland, J. Karavidopoulos, C. Martini, B. Metzger, Novum Testamentum Graece (28th Edition), Stuttgart 2012.

80 Jeśli nie zaznaczono inaczej, wszystkie cytaty w jęz. polskim pochodzą z: Pismo Święte Starego i Nowego Testamentu, Pallottinum 2010.

81 Pismo Święte Starego i Nowego Testamentu, Edycja św. Pawła, Częstochowa 2008. 
Jej przyczyna leży poza sferą biologiczną. Biologia śmierci jest niejako podporządkowana jej przyczynie nadprzyrodzonej - grzechowi. Człowiek musi umrzeć, ponieważ jest to konsekwencja grzechu ${ }^{82}$.

W ten sposób uwyraźnia się jasne przekonanie, że człowiek rodzi się skażony grzechem, który teologia nazwała pierworodnym. Stąd nasuwa się prosty wniosek: czyny ludzkie nie mogą być i w istocie nie są dobre same w sobie. Człowiek, nie tracąc swojej wrodzonej godności, traci obiektywne odniesienie do dobra. Możliwość spełniania dobra została upośledzona, co jest konsekwencją panowania w człowieku pożądliwości. Te z kolei ukierunkowują człowieka w stronę własnych, egoistycznych potrzeb, nie zaś w stronę obiektywnego dobra. Zniszczona, czyli ukierunkowana ku złu, natura człowieka jest przekazywana przez zrodzenie. Przestępstwo Adama spowodowało zatem głębokie rozdarcie. Adam i Ewa nie mogli już przekazywać natury „rajskiej”, skoro sami się jej pozbawili. Ta zależność rozciąga się na ludzi wszystkich czasów, aż do skończenia świata.

\section{POWSZECHNOŚĆ ŚMIERCI A GRZECH PIERWORODNY W MDR 2,23-24}

Fragment Księgi Mądrości omawiany w ramach tego artykułu uzupełnia zaprezentowaną powyżej teologię św. Pawła o wymiar starotestamentalny ${ }^{83}$. Przywoływane wersy wpisują się w obszerniejszy fragment $(1,16-2,24)$, omawiający pogańską wizję świata ${ }^{84}$. Autor zauważa i surowo potępia egzystencję materialistyczną, która wykluczając życie po śmierci, prowadzi w konsekwencji do poważnych następstw moralnych: zachłanności, przemocy, niesprawiedliwości i bezbożności ${ }^{85}$. Hagiograf mówi o bezbożnych, którzy uciekają przed Bogiem, podążając ku śmierci ${ }^{86}$. Jak zauważa Poniży (cytując K. Romaniuka), owi bezbożni charakteryzują się pragnieniem trwałej łączności ze śmiercią ${ }^{87}$. Widać zatem, że autor Mdr rysuje obraz człowieka łudząco przypominający obraz człowieka ponowoczesnego, eugenicznie zmutowanego człowieka XXI wieku, który pędzi ku śmierci, pożądając jej. Skoro życie jest przelotne i szybko się kończy, to nie pozostaje nic innego, jak czerpać zeń jak najwięcej korzyści i przyjemności ${ }^{88}$. Nie opłaca się również pomagać ubogim i dbać o bliźnich, stąd bezbożni zwracają się

82 Należałoby szerzej rozwinąć kwestię śmierci jako kary za grzech. Zagadnienie to przekracza jednak problem mojego artykułu. Por. I. Mroczkowski, Zło i grzech: studium filozoficzno-teologiczne, Lublin 2000.

83 Wprowadzenie do Mdr zob. D. Winston, The Wisdom of Salomon, Doubleday 1979, s. 3-69.

84 B. Poniży, Księga Mądrości. Od egzegezy do teologii, Poznań 2000, s. 27.

85 Tamże.

86 Tamże.

87 Tamże

88 Tamże, s. 28. 
przeciwko nim ${ }^{89}$. Przyczyn takiego stanu rzeczy autor upatruje w niezrozumieniu „tajemnic Bożych”, nazywanych przezeń postępowaniem Boga z pobożnymi, którzy po próbach i prześladowaniach otrzymują życie wieczne ${ }^{90}$. W tym kontekście pojawiają się omawiane w tym artykule wersety, które zdają się wskazywać na istotę błędnego postępowania bezbożnych. Żyjąc niezgodnie z Bożym prawem, odrzucając Boże przykazania, nie rozumieją głębi Bożych planów, ponieważ Bóg stworzył człowieka do nieśmiertelności, na swój obraz i podobieństwo, a śmierć jest działaniem diabła. Nieśmiertelność oraz obraz i podobieństwo Boże jawią się zatem jako ontologiczny punkt wyjścia dla istnienia człowieka i jego osobowej godności, a także dla jego moralności. Ponieważ nieśmiertelność jest intencjonalnym założeniem bytu ludzkiego, a zakorzeniona jest w obrazie Bożym, to jej odrzucenie jest odrzuceniem istoty człowieka jako takiego. Innymi słowy: odrzucenie transcendentnej wartości bytu ludzkiego i ograniczenie go do absolutnie immanentnego względem rzeczywistości materialnej odcina ontologiczny korzeń osoby ludzkiej, czyniąc człowieka jedynie zwierzęciem wyższego rzędu. Bez esencjalnego uznania nieśmiertelności i podobieństwa Bożego nie ma mowy o egzystencjalnym przeżyciu godności.

Wzmianka o stworzeniu człowieka na obraz Boga (na wzór Jego nieśmiertelności) zdaje się odniesieniem do teologii stworzenia z Rdz 1,26, wspominania zaś w Mdr 2,24 zawiść diabła ma zapewne przywołać grzech pierwszych rodziców i rolę szatana w nieposłuszeństwie Adama i Ewy ${ }^{91}$. Autor Mdr nie cytuje, rzecz jasna, Rdz dosłownie. Księga początku jest dla hagiografa mądrościowego tłem teologicznym. Zawiść diabła, o której tu mowa, bywa przez niektórych kojarzona również z grzechem Kaina, który przez zawiść zabija Abla ${ }^{92}$. Taka interpretacja wskazywałaby na przechodzenie grzechu z Adama na Kaina, co oznacza, że Kain utracił zdolność czynienia zawsze dobra, gdyż wydany na pastwę swoich pożądliwości zabija brata.

\section{NAUCZANIE KOŚCIOŁA}

\section{ISTOTA GRZECHU PIERWORODNEGO}

Zaprezentowane teksty biblijne rzucają jasne światło na podejmowane przeze mnie zagadnienie. Pozwalają też spojrzeć na problem optymizmu antropologicz-

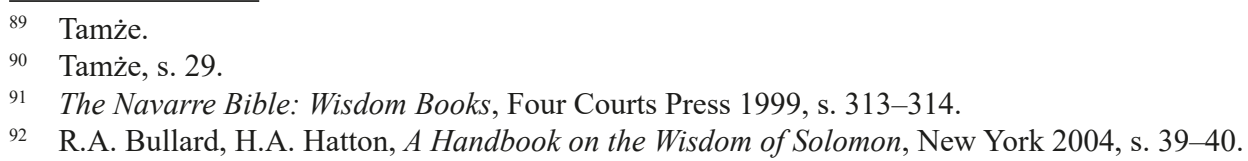


nego z innej niż dotychczas perspektywy. W poszukiwaniu źródeł optymizmu $\mathrm{w}$ antropologii starałem się zrozumieć, jak postrzegana jest natura ludzka. Teksty biblijne ujawniły jednak jeszcze nowy aspekt zagadnienia - pojęcie śmierci. Konsekwencją grzechu pierworodnego jest śmierć i słabość. Te zaś optymistom jawią się jako wróg człowieka i w tym nauka kościelna i prezentowane poglądy niekościelne się zgadzają. Jednak próba rozwiązania problemu jest inna. Wydaje się, że problem śmierci jest o wiele bardziej złożony, dlatego w tym miejscu sygnalizuję jedynie jego pojawienie się. Zasługuje on na osobne opracowanie. Jeśli chodzi jednak o analizę tego tematu po stronie katolickiej, to nieoceniony wkład w to zagadnienie wniósł J. Ratzinger. Zebrał on również bogatą literaturę, przede wszystkim w swoim dziele Eschatologia - śmierć i życie wieczne ${ }^{93}$. J. Ratzinger zauważa, że stosunek do śmierci we współczesnym świecie jest niespójny ${ }^{94}$ z jednej strony jest ona przemilczana, z drugiej robi się zeń ,widowisko”, jak stwierdza Ratzinger ${ }^{95}$. Człowiek skupiony na tu i teraz zapomina o konieczności śmierci. Śmierć jest według Ratzingera tematem tabu. Podobne przekonanie o śmierci jako czymś wstydliwym panuje również dzisiaj, jest ono jednak nieco inaczej tabuizowane. Technika pozwala na przesunięcie granicy śmierci. Strach przed nią jest dzięki temu mniejszy, ponieważ ufa się medycynie i technice na tyle, że duża część społeczeństwa wierzy w potencjalną nieśmiertelność w czasie tego życia. Rozwój idei materialistycznych oraz przenikająca do kultury zachodniej idea reinkarnacji i nirwany pozwoliły wyprzeć strach przed śmiercią. Ci, którzy uważają, że po śmierci nic nie ma, chętnie poddają się eutanazji. Inni sądzą, że ewentualne życie po śmierci jest raczej rozpłynięciem się w energii kosmosu ${ }^{96}$.

Łatwo zauważyć, że tabuizacja śmierci jest połączona z możliwością nieskrępowanej realizacji aktów woli i odruchów naturalnych. Brak śmierci bądź jej błędne pojmowanie zrzuca bowiem z jednostki odpowiedzialność moralną i konsekwencje własnych czynów.

Wracając do głównego zagadnienia, należy za Katechizmem Kościoła katolickiego zauważyć, że zrozumienie grzechu musi zacząć się od zauważenia głębokiej

93 Zob. J. Ratzinger, Eschatologia - śmierć i życie wieczne, w: J. Ratzinger, Opera omnia, t. 10, tłum. J. Kobienia, Lublin 2014, s. 86-113.

94 Książkę tę J. Ratzinger publikuje w 1977 r.

95 Zob. J. Ratzinger, Eschatologia ..., s. 86-87.

96 Portal Netflix wyemitował serial pt. Dobre miejsce. Fabuła zakłada, że ludzie skazani na piekło mogą przejść kurs etyki i jeśli zaliczą egzamin, mogą dostać się do nieba. Tam mogą robić wszystko, co im się podoba, bez ograniczeń, chorób, cierpień, pracy - wszystko samo się dzieje. Kiedy jednak znudzą się życiem po śmierci, mogą przejść przez drzwi i przestać istnieć. Ich byt się ,ulatnia”. 
więzi człowieka z Bogiem ${ }^{97}$. Nieco dalej Katechizm stwierdza, że zrozumienie, czym jest grzech pierworodny, możliwe jest tylko wtedy, jeśli pozna się Chrystusa jako źródło łaski ${ }^{98}$. Język Biblii $\mathrm{w}$ obrazowy sposób prezentuje przekonanie, że od początku historii człowieka towarzyszy mu jakaś pierwotna wina i że jest nią naznaczona cała ludzkość ${ }^{99}$. Istotą grzechu pierworodnego jest nieposłuszeństwo okazane Bogu, nieufność wobec Stwórcy i przedłożenie siebie ponad Boga. Utracona zostaje pierwotna harmonia ${ }^{100}$. Sobór Trydencki zaś stwierdza, że grzechu tego nie można zgładzić „siłami natury ludzkiej lub innym środkiem zaradczym”. Może tego dokonać tylko zasługa Jezusa Chrystusa ${ }^{101}$.

\section{SKUTKI GRZECHU PIEROWORODNEGO}

Ten sam Sobór stwierdza, że wina Adama, rozciągając się na cały rodzaj ludzki, spowodowała utratę świętości i sprawiedliwości otrzymanych od Boga ${ }^{102}$. Oczywiście grzech pierworodny nie jest czymś w rodzaju winy zbiorowej ${ }^{103}$. Powszechność grzechu pierworodnego, która jest jednym z jego skutków, wynika raczej z solidarności rodzaju ludzkiego, w tym sensie, że wszyscy mamy jedną i tę samą naturę ${ }^{104}$. J. Rahner zauważa również, że doktryna o grzechu pierworodnym, oprócz utraty świętości i sprawiedliwości, zmusza do przemyślenia jego innych skutków: „utraty tak zwanych pozanaturalnych darów stanu pierwotnego, kwestię wolności od pożądania (pożądliwości) oraz kwestię niepodlegania konieczności śmierci" 105 . G.L. Müller ujmuje rzecz nieco bardziej egzystencjalnie, mówiąc o utracie bliskości Boga ${ }^{106}$. Idąc za św. Pawłem, zwraca uwagę na utratę chwały Bożej, gniew Boży (całkowite odwrócenie się od świętości Boga) i śmierć ${ }^{107}$.

Jak w konsekwencji wygląda po grzechu pierworodnym natura ludzka? Bonifacy II zauważa, że została ona zdeprawowana przez grzech Adama ${ }^{108}$. Felix III

KKK 386.

$98 \quad$ KKK 387.

99 KKK 390.

100 KKK 397-399.

101 Zob. Sobór Trydencki, Dekret o grzechu pierworodnym, w: Dokumenty soborów powszechnych, t. IV/1, red. A. Baron, H. Pietras, Kraków 2007, s. 237.

102 Tamże.

103 Por. K. Rahner, Pisma wybrane, t. 2, thum. G. Bubel, Kraków 2007, s. 56.

104 Por. tamże, s. 57.

105 Tamże, s. 61.

106 Zob. G.L. Muller, Dogmatyka katolicka, tłum. W. Szymona, Kraków 2015, s. 165.

107 Tamże.

108 Bonifacy II, Per filium nostrum, w: H. Denzinder, Enchiridion symbolorum, definitionum et declarationum de rebus fidei et morum, $43^{\text {rd }}$ Edition, $\mathrm{nr} 400$. 
z kolei stwierdza, że grzech pierworodny rozciąga się nie tylko na ciało, ale też na duszę. Ta zaś w jego wyniku traci wewnętrzną wolność ${ }^{109}$. Sobór Watykański II, analizując społeczny wymiar życia ludzkiego, wtrąca niejako marginalnie bardzo ważne zdanie: ,człowiek z natury skłonny do złego znajduje ciągle nowe podniety do grzechu" ${ }^{\prime 10}$.

\section{PODSUMOWANIE}

Oba teksty biblijne tworzą zatem ciekawą inkluzję. Czerpiąc tło teologiczne z Księgi Rodzaju, wskazują na praprzyczynę śmierci - jest nią grzech Adama. Śmierć człowieka stoi w opozycji do nieśmiertelności Boga. Owa nieśmiertelność jest jednak opozycją szczególną. Chodzi bowiem o opozycję niewrodzoną, ale uczynioną. Mowa o fakcie stworzenia natury ludzkiej jako dobrej, ale skorumpowanej ostatecznie przez grzech Adama. To skorumpowanie jest niepokonalne. Czyn niesprawiedliwy jednego musi zostać pokonany przez czyn sprawiedliwy innego (Chrystusa). Ta zależność pozwala zrozumieć dalsze części obu omawianych fragmentów, które w tym artykule nie zostały poddane analizie. Księga Mądrości mówi jedynie o odmiennym losie sprawiedliwych i niesprawiedliwych. Autor zdaje się uznawać, że można dobrze postępować, jedynie wypełniając Boże prawa. Nie mówi jednak o odnowieniu natury ludzkiej na poziomie ontycznym. Stąd czyn człowieka o tyle jest dobry, o ile jest zakorzeniony w boskim prawie miłości i sprawiedliwości. Paweł wskazuje już na odkupieńcze dzieło Chrystusa, które przywraca naturę ludzką do porządku łaski. I to właśnie ów nowy porządek łaski jest najbardziej jaskrawym tłem optymizmu antropologicznego. Okazuje się bowiem, że w perspektywie Pawłowej doświadczamy przeciwstawienia sobie człowieka nowego i starego. Nie można więc mówić o powszechnej i jednolitej tkance ludzkiej. Ludzie są równi co do natury, godności i dziecięctwa Bożego. Jednak są różni co do stanu łaski.

Taka interpretacja grzechu pierworodnego stała się podstawą wypowiedzi Magisterium Kościoła o grzechu pierworodnym. Z perspektywy niniejszego artykułu najistotniejsze wydaje się jednak stwierdzenie, że człowiek ciąży ku grzechowi. Oznacza to, że jego natura, nosząca na sobie konsekwencje grzechu pierworodnego, nie ciąży w sposób naturalny do dobra, ale do grzechu. Grzech natomiast jawi się jako zło moralne.

109 Felix III, Dekrety synodu w Orange, w: H. Denzinger, Enchiridion..., nr 371.

110 Konstytucja „, Gaudium et spes”, nr. 25: [...] homo, proclivis ad malum natus, nova deinde ad peccatum incitamentia invenit (tekst oryg. za: H. Denzinger, Enchiridion..., nr. 4325) 


\section{ZAKOŃCZENIE}

Zaprezentowane przeze mnie poglądy na temat optymizmu antropologicznego i ich zestawienie $\mathrm{z}$ nauką o grzechu pierworodnym pozwalają na wysnucie wniosków będących jednocześnie odpowiedzią na postawiony we wstępie problem. Optymizm antropologiczny zakłada, że człowiek jest z natury dobry i wszystkie jego akty, o ile nie zostaną zdeprawowane przez kulturę, też są dobre. Zło pochodzi niejako z zewnątrz, nie wynika ono z wrodzonych uwarunkowań człowieka. Teologia katolicka również naucza, że człowiek został stworzony jako dobry. Pierwotne dobro człowieka zostało jednak zdeprawowane przez nieposłuszeństwo Bogu. Owo nieposłuszeństwo stało się przyczyną zerwania jedności między Bogiem i człowiekiem. Człowiek duchowo oderwany od łaski ukierunkował się w konsekwencji ku złu. Zło i grzech stały się naturalnym wyborem człowieka. Ujawnia się tu pierwsza różnica. Chociaż obie doktryny zakładają pierwotne dobro człowieka, to jednak optymizm nie przyjmuje zranienia natury ludzkiej. Dlatego z konieczności zło jest dlań wynikiem deprawacji kulturowej.

Oba poglądy wykluczają się wzajemnie, więc rodzi się pytanie, który z nich jest prawdziwy. Nauka o grzechu pierworodnym jest zdogmatyzowana, więc a priori można stwierdzić, że optymizm antropologiczny się myli. Warto jednak zawiesić pewność dogmatu i spróbować rozstrzygnąć zagadnienie. Kultura według optymizmu antropologicznego prowadzi człowieka do złych wyborów. Odruchy pierwotne są jednak z natury dobre. Czy jednak kultura nie jest wytworem ludzkim? Jest i to w najwłaściwszy sposób. Jest ona też niejako odruchem pierwotnym człowieka, co potwierdza archeologia. Już najbardziej prymitywni ludzie zostawili po sobie przejawy kultury. Duchowość zatem jest jakimś wewnętrznym imperatywem człowieka. Proste wnioskowanie prowadzi zatem do konkluzji: kultura deprawuje człowieka, ale sama jest wytworem ludzkim, wypływającym $\mathrm{z}$ wnętrza osoby. Zło zatem bierze się w świecie z wnętrza osoby ludzkiej.

Zagadnienie nie jest jeszcze do końca jasne. Rodzi się bowiem pytanie o jaskrawą różnicę w pojmowaniu natury. Transhumanizm, w ślad za marksizmem, utrzymuje, że nie ma jednej, stałej natury ludzkiej. Człowiek jest co do natury labilny. Nie istnieje żadna sfera duchowa, która nadawałaby człowiekowi jakiś stały „kształt”. Wszyscy jesteśmy równi i mamy dążyć do równości, powie Engels, nie wyjaśnia jednak, na czym konkretnie owa równość bazuje. Sprawę kwituje stwierdzeniem, że równość wynika z godności osobowej. Na czym jednak osadza się owa godność, jeśli nie na stałej i niezmiennej naturze? Podobnie transhumanizm stawia pod znakiem zapytania kwestię duchowej natury człowieka. Natura jest raczej zespołem jakichś cech biologicznych. Nietrudno zauważyć, że problem natury jest problemem materialistycznej koncepcji świata. I znowu zło nie może 
pochodzić z wnętrza osoby, gdyż nie ma ona niejako wnętrza. Tym razem jednak zło jest spowodowane uciskiem burżuazji czy brakiem optymalizacji.

Ostatecznie optymizm antropologiczny nie wprost, ale wywołuje temat śmierci. Jest ona najprostszą konsekwencją grzechu pierworodnego. Temat śmierci jest jednak zbyt szeroki, co już zasygnalizowałem, pominę więc teraz tę kwestię.

Odpowiadając wprost na postawione we wprowadzeniu pytanie, stwierdzam, że nauka o grzechu pierworodnym pozwala zrozumieć lepiej istotę optymizmu antropologicznego, dojść do przekonania, że jest to pogląd błędny i zrozumieć istotę tego błędu. Jest to o tyle ważne, że jak wskazałem we wstępie, idee przekładają się znacząco na życie jednostek. Rezygnacja z katolickiego pojmowania natury ludzkiej, a tym samym natury zła, prowadzić może do lepszego samopoczucia, ale jednocześnie przemilcza konieczność zbawienia. Optymizm antropologiczny niemalże wprost głosi autosoteriologię. Człowiek zbawia się sam. Już termin zbawienia nabiera nowego wydźwięku i oznacza optymalizację.

\section{BIBLIOGRAFIA}

Aland B., Aland K., Karavidopoulos J., Martini C., Metzger B., Novum Testamentum Graece (28th Edition), Stuttgart 2012.

Alichniewicz A., Michałkowska M., Udoskonalanie gatunku ludzkiego - problemy definicyjne $i$ argumentacyjne, „Principia” LXIV (2017), s. 225-255.

Baranowska M., Jana Jakuba Rousseau refleksja o naturze czlowieka, E-Wydawnictwo. Prawnicza i Ekonomiczna Biblioteka Cyfrowa, Wydział Prawa, Administracji i Ekonomii Uniwersytetu Wrocławskiego, za: http://www.repozytorium.uni.wroc.pl/Content/66121/04_Marta_Baranowska.pdf [dostęp: 18.07.2019].

Bonifacy II, Per filium nostrum, w: H. Denzinder, Enchiridion symbolorum, definitionum et declarationum de rebus fidei et morum, $43^{\text {rd }}$ Edition.

Bullard R.A., Hatton H.A., A Handbook on the Wisdom of Solomon, New York 2004.

Byrne B., Romans, Collegville 1996.

Ciniewski P., Ambiwalencja transhumanizmu wobec cielesności, „Filozofia i Nauka. Studia Filozoficzne i Interdyscyplinarne" 5 (2017), s. 105-116.

Coplestone F., Historia filozofii, t. 7, Warszawa 1995.

Delsol Ch., Esej o czlowieku późnej nowoczesności, thum. M. Kowalska, Warszawa 2003.

Delsol Ch., Nienawiść do świata. Totalitaryzmy i ponowoczesność, tłum. M. Chojnacki, Warszawa 2017.

Dessain C.S., The Acts of the Apostles, w: A Catholic Commentary on Holy Scripture, red. B. Orchard, E.F. Sutcliffe, Toronto 1953.

Dunn J., Word Biblical Commentary, vol. 38a: Romans 1-8, Dallas 1988.

Edwards J.R., Romans, Baker Books 1992. 
Engelhardt H.T. Jr., The Foundations of Bioethics, Oxford 1996.

Engels F., Rozwój socjalizmu od utopii do nauki, Warszawa 2007.

Felix III, Dekrety synodu w Orange, w: H. Denzinder, Enchiridion symbolorum, definitionum et declarationum de rebus fidei et morum, $43^{\text {rd }}$ Edition.

Ferdynus M., Czy biomedyczne doskonalenie natury jest „zabawa w Boga”?, „Studia Warmińskie" 50 (2013), s. 9-22.

Fitzmyer J.A., Romans, New York 1993.

Johnson L.T., Reading Romans. A Literary and Theological Commenatry, Smyth \& Helwys Publishing 2001.

Karoń K., Historia antykultury, Warszawa 2018.

Konstytucja Duszpasterska o Kościele w świecie współczesnym „,Gaudium et spes”, w: H. Denzinger, Enchiridion symbolorum, definitionum et declarationum de rebus fidei et morum, $43^{\text {rd }}$ Edition.

Lindenberg G., Ludzkość poprawiona. Jak najbliższe lata zmienia świat, w którym żyjemy, Kraków 2018.

Łukasiewicz K., Nadnatura. Wizje człowieka przyszłości we współczesnej debacie naukowej, popu- larnonaukowej i fantastycznonaukowej, „Prace Kulturoznawcze” XIV (2012) 2, Natura (w) granica(ch) kultury, red. I. Topp.

Marks K., Engels F., Manifest Partii Komunistycznej, Studenckie Koło Filozofii Marksistowskiej (Uniwersytet Warszawski), Warszawa 2007.

Marx K., Theses on Feuerbach, https://www.marxists.org/archive/marx/works/1845/theses/theses.html [dostęp: 22.08.2019].

Moo D.J., The Epistle to the Romans, William B. Eerdmans Publishing Co. 1996.

Mroczkowski I., Zło i grzech: studium filozoficzno-teologiczne, Lublin 2000.

Muller G.L., Dogmatyka katolicka, tłum. W. Szymona, Kraków 2015.

The Navarre Bible: Wisdom Books, Four Courts Press 1999.

Poniży B., Księga Mądrości. Od egzegezy do teologii, Poznań 2000.

Rahner K., Pisma wybrane, t. 2, tłum. G. Bubel, Kraków 2007.

Ratzinger J., Eschatologia - śmierć i życie wieczne, w: J. Ratzinger, Opera omnia, t. X, tłum. J. Kobienia, Lublin 2014.

Rockmore T., Marx after Marxism. The Philosophy of Karl Marx, Blackwell Publishers 2002.

Rouseau J.J., Emil, or on Education, Basic Books 1979.

Rouseau J.J., Origin and Foundations of Inequality Among Mankind, w: The Social Contract and the First and Second Discourses, Yale University 2002.

Sandel M.J., The Case Against Perfection. Ethics in the Age of Genetic Engineering, Harvard University Press 2007.

Shore C., Wright S., Anthropology of Policy: Perspectives on Governance and Power, Routledge 2003. 
Sobór Trydencki, Dekret o grzechu pierworodnym, w: Dokumenty soborów powszechnych, t. IV/1, red. A. Baron, H. Pietras, Kraków 2007.

Soniewicka M., Transhumanizm: kilka uwag na temat filozoficznych źródet sporu o idee biomedycznego ulepszania moralnego, „Ethics in Progress” 6 (2015), s. 38-55.

Walker D., Gray D., Historical Dictionary of Marxism, The Scarecrow Press 2007.

Winston D., The Wisdom of Salomon, Doubleday 1979.

Zawadzka S., Wolność ludzka w ujęciu Jana Jakuba Rousseau, „Studia Philosophiae Christianae UKSW" 52 (2016) 1, s. 121-135.

\section{ANTHROPOLOGIAL OPTIMISM IN THE PERSPECTIVE OF THE DOCTRINE OF ORIGINAL SIN}

\section{Summary}

Original sin has destroyed human nature. Man redeemed by Christ is constantly suffering the consequences of this corruption. However, observing modern society, one can get the impression that many thinkers and scientists do not seem to understand what the consequences of original sin are, and thus fall into too optimism. This optimism was called by the author anthropological optimism. Presenting three manifestations of this optimism, the author sought the answer to the question whether the science of original sin somehow influences its understanding and whether it can help to assess this optimism. Using the methods available to him, the author came to the conclusion that the current of his thought contradicts the science of original sin, which constitutes its falsehood. It follows that the practical application of anthropological optimism can lead to humiliation of the dignity of the human person, unsustainable human development, and the establishment of rights incompatible with the proper human dignity. The author finally notes that the current social situation, which is largely due to the practical use of the idea of anthropological optimism, requires constant deepening and courageous opposition to it.

Keywords: anthropology, transhumanism, original sin, human nature, anthropological optimism, the human person

\section{OPTYMIZM ANTROPOLOGICZNY W ŚWIETLE NAUKI} O GRZECHU PIERWORODNYM

\section{Streszczenie}

Grzech pierworodny zniszczył naturę ludzką. Człowiek odkupiony przez Chrystusa ponosi ciągle konsekwencje tego zepsucia. Obserwując jednak współczesne społeczeń- 
stwo, można jednak odnieść wrażenie, że wielu myślicieli i naukowców zdaje się nie pojmować, czym w istocie są konsekwencje grzechu pierworodnego, przez co popadają w zbytni optymizm. Optymizm ten został nazwany przez autora optymizmem antropologicznym. Prezentując trzy przejawy tegoż optymizmu, autor szukał odpowiedzi na pytanie, czy nauka o grzechu pierworodnym wpływa jakoś na pojmowanie go i czy może ona pomóc ten optymizm ocenić. Stosując dostępne sobie metody, autor doszedł do wniosku, że prezentowany przez niego nurt myślowy stoi w sprzeczności z nauką o grzechu pierworodnym, co stanowi o jego fałszywości. Wynika stąd, że praktyczne zaaplikowanie optymizmu antropologicznego może prowadzić do poniżenia godności osoby ludzkiej, niezrównoważonego rozwoju człowieka, ustanawiania praw niezgodnych z właściwą godnością człowieka. Autor zauważa ostatecznie, że obecna sytuacja społeczna, wynikająca w dużej mierze z praktycznego wykorzystania idei optymizmu antropologicznego, wymaga ciągłego pogłębiania i odważnego przeciwstawiania się jej.

Słowa kluczowe: antropologia, transhumanizm, grzech pierworodny, natura ludzka, optymizm antropologiczny, osoba ludzka 